\title{
Are Crime Victims Being Gagged Under the Israeli Criminal Justice Procedures?
}

\author{
Efrat Shoham ${ }^{1, *}$ and Lior Gideon, ${ }^{2, *}$ \\ ${ }^{1}$ Department of Criminology, Ashkelon Academic College, Ashkelon, Israel \\ ${ }^{2}$ Department of Law, Police Science and Criminal Justice Administration, John Jay College of Criminal \\ Justice, 899 Tenth Ave., New York, NY 10019, USA
}

\begin{abstract}
In this conceptual article we examine the issues revolving around crime victims' participation under the Israeli criminal procedure in recent years. As such, the article discusses the official status of victims, the protections guaranteed by local legislation during the various legal stages--beginning with the criminal investigation procedure through the protections guaranteed under law, and their routine implementation. Specifically, the article discusses changes in Israeli legislation and practice in regard to victims' rights, while comparing them to those in other countries. Further, the article discusses the introduction of restorative justice to legal procedures in Israel, and its relevance to victims' rights. It concludes with a recommendation to establish a standardized policy that will assure victims' rights in order to secure their status while also ensuring that they are being exposed to a therapeutic process that is much needed for the victims, and in particular for domestic and sexual assault victims.
\end{abstract}

Keywords: Victims' Impact Statement, Sexual victimization, Victims rights, Domestic Violence, Restorative Justice.

\section{INTRODUCTION}

The State of Israel was among the first to join the United Nations (UN) treaty, in the mid. 80's, calling for justice to crime victims, by promoting their engagement in the criminal process (Yanai, 2003). Alas, almost two decades went by before Israel actually began to establish crime victims' rights by primary legislation.

The present article is a conceptual study that aims to present and examine the issues revolving around the involvement of crime victims in the Israeli criminal procedure at the beginning of the current century. Consequently, this article will discuss the official status of victims and related protections guaranteed during the various stages of the criminal investigation and legal procedure, and their implementations in everyday life.

\section{HISTORICAL CONTEXT}

Under the Israeli justice system, crime victims are considered witnesses of the prosecution; however, most times they were prevented from voicing their experience during the various stages of the legal procedure. Accordingly, in 1987, Judith Carp, then the deputy to the Israeli Attorney General, argued that victims of crimes are the "step-sons" of the criminal

${ }^{*}$ Address correspondence to these authors at the Department of Criminology, Ashkelon Academic College, Ashkelon, Israel; Tel: 086789232;

E-mail: shoham@netzer.org.il

Department of Law, Police Science and Criminal Justice Administration, John Jay College of Criminal Justice, 899 Tenth Ave., New York, NY 10019, USA;

Tel: (212) - 237-8991; E-mail: Igideon@jjay.cuny.edu justice system; they feel used, drained and neglected (see Shoham \& Regev, 2008).

In March of 1992, the legislation of the Israeli bill of rights ${ }^{1}$ (Israel currently has no constitution but a bill of rights known as: "The Basic Law: Human Dignity and Freedom"), dramatically changed criminal law procedures, shifting it from a "crime control" approach to that of "due process", while acknowledging the victim's legal rights. Three years later, in 1995, Chief Justice Shamgar ${ }^{2}$ claimed that The Basic Law: Human Dignity and Freedom (from here on BLHD\&F), carries with it a legal responsibility not just for criminals but for the victims of their crimes as well. Yet, such understanding was not implemented. In fact, toward the end of 1998 the Israeli Supreme Court ruled that "...the traditional legal system in Israel does not allow victims of crime to be part of the procedure taken against the aggressor. The victim's status in court is that of a prosecution witness and its role is to assist the court in finding the truth." As such, the Israeli Supreme Court shifted the responsibility from the courts to the legislator.

However, the end of the 90's was characterized by a renewed and ongoing debate over the rights of victims. Such debate rose to public awareness as more voices called to enable victims to actively participate in the various stages of the criminal procedure. The

${ }^{1} 68$ (1391), March, $25^{\text {th }} 1992$, p. 150.

${ }^{2}$ DN"P 2316/95 Imad Gnimat v. State of Israel 49(4), 589

${ }^{3}$ Translated from Hebrew BG"Z7673/98 Elkyam v. Israeli Governmental Legal Counsel, Dinim Elion 55, 286. 
discourse resulted in ongoing disputes among members of the legal community-and other criminal justice professionals-calling to include the victim as a "third wheel" to an adversary legal system, where there are only two sides: the state and the accused. Such call, presented a legal challenge-justifiable as it may be-on the manner in which to integrate the victim in to such procedure. According to Sebba (2000), such challenge was not quickly acknowledged by the legal system that did not offer any meaningful amendments to enable such inclusion. This legal limbo changed with the new Victim of Crime Rights Act of 2001, legislation.

\section{The Victims of Crime Rights Act of $2001^{4}$ : Current Situation}

The Victims of Crime Rights Act of 2001 brought with it a new massage placing the victim as an important source of input to the criminal procedure. The actual combination of the words "rights" and "crime victims"-a combination that previously was solely identified with accused and suspects-symbolized a new era according to which victims will no longer be ignored and forgotten by the criminal justice system during its criminal procedure. According to Windman (2001), this new era entitled victims to voice their experience while being acknowledged in the criminal procedure.

As discussed earlier, before the Act victims were perceived as witnesses of the prosecution, and as such were disenfranchised from justifiable legal rights; a situation that lead to victims being almost completely ignored, and the harm caused to them by the crime neglected. The victims' diminished role in the criminal procedure is incomprehensible, and makes very little sense as to how such approach governed the criminal procedure for so long.

With the legislation of the Victims of Crime Rights Act in $2001^{5}$, the spot light of the criminal procedure was now directed to the victims as well. According to its manifested goals, such act is designed to establish, for the first time, the responsibility of the state to protect the rights, human dignity and privacy of the victim while considering their needs during the entire criminal process; while at the same time ensure the rights of suspects, accused and convicted offender responsible

\footnotetext{
${ }^{4}$ Published on March $21^{\text {st }}, 2001$, page 183 , and again on May $24^{\text {th }}, 2001$, page 390.

${ }^{5}$ The assimilation of the act was designed to stretch over an eight years period and has not been completed yet.
}

for the victimization. The Act identifies the victim as a person who has directly affected by the criminal offense, along with family members of victims who died as a result of the criminal act.

The amendments to the Israeli legislation distinguishes between three categories of crime victims:

1. Victim of criminal offense

2. Victim of sexual or violent offense

3. Victim of sexual or serious violent offense.

Each of the above crime categories is inclusive of the lower category, and the victim of such offense is entitled to all rights and remedies guaranteed under such category and its foregoing category. Unfortunately, budgetary and other difficulties that rose during the implementation of the act resulted in a number of amendments that enabled its implementation only for those victims defined by the third category mentioned above-victims of sexual or serious violent offense (Shoham \& Regev, 2008).

\section{The Victim Impact Statement}

The legal reform associated with the 2001 Victims of Crime Act, tentatively paved the way for many victims to share their experience, and relate the harm done to them by the crime. However, victims' impact statements did not experience a "smooth sailing", and became a hub of controversy (Davis \& Smith, 1994). The main argument that is usually been presented against allowing the victim to voice his experience during the criminal procedure revolve around issues that may be perceived as violation of due process, and in particular harming the basic rights of the accusedwhich is assumed to be innocent until proven guilty beyond reasonable doubt (Zaltzover, 2004). Thus, affecting the adversary legal system; using the victim to increase punitiveness while also creating massive strain and irrational expectations on the victim part (Bar-Zohar, 2008). In other words, enabling the victim to express her/ his experience and concern may come at a cost for the defendant, and as a result reduce uniformity in sentencing while promoting greater arbitrariness (Abramovsky, 1986; Talbert, 1988). Rubel (1986) expressed concern that judges' ability to resist public pressure will be compromised. Previous studies examined the integration of the victim's subjective statement-known as the Victim's Impact Statement (VIS) (here on will be presented as either 'statement' or 
in its full version, 'victim impact statement')—describing how being a victim of crime has affected the victim and others, close to him, focusing on the consequences of the criminal act on different aspects of the victim's life, such as physical, emotional, economical and so on (see Erez, 1999; 2000). These studies-mainly conducted in the US and Australia-demonstrated that victims' impact statements did not result in higher, or more sever punishments (see Davis \& Smith, 1994), but did result in a renewed approach by the prosecutor and judge (Erez \& Rogers, 1999). Many times, the preparations of the statements are conducted by special agencies, and not directly by the victim, and thus the argument according to which such statements may be used as a tool to avenge the perpetrator has little validity.

The argument according to which cross examination of the victim can lead to unnecessary stress, and pressure was also found to be unsubstantiated (Shoham \& Regev, 2008). Contrary, the victim impact statement was aimed to allow crime victims to present the criminal incident from their own perspective and experience; however, the preparation of the statement by formal objective broker may also result in the loss of important details and even the adaptation of the statement to comply with the court and legal system needs (Erez, 2000).

In the adversarial system, that is customary in Israel, the victims' standpoint was seldom addressed and thus was never taken into consideration. This is especially true if a plea bargain was made, or if the case was dismissed due to insufficient evidence, or due to lack of public interest. This is particularly true for sex crimes, where more than half of the criminal cases end in plea bargain (Kama, 2007).

Studies have shown that many crime victims are willing to share their experience (Erez \& Tonodonato, 1990; Erez \& Rogers, 1999; Hoyle, 1998, Roberts, 2003). In fact, Farkash (2001) found that those victims whose evidence was considered in the form of a victim's impact statement, reported being relieved, satisfied, and being better able to coop with their victimization. Further, increased satisfactions accompanied cases where the judge mentioned or even quote sections from the statement. According to Ben David (2003), introducing the victims' subjective story into the different stages of the criminal procedure does not threat the existing legal structure and does not attempt to affect the goals of punishment. Introducing the victims' impact statement is done mainly to allow the victim to voice his/ her subjective experience. Ben-David (2003), argued that coalescing the victims' evidence in the different stages of the criminal procedure does not aim to alter existing legal structures, and not even to reformulate the goals of punishment. Incorporating the victims' evidence in the legal procedure is first and foremost to allow the victim to simply voice his experience, and that is the main function of involving the victim in the procedure. Similarly, Des-Rosiers, Feldthusen, and Hankivsky (1998) found in a study of sexual crime victims in Canada that victims are often searching for a public affirmation of the wrong that they suffered.

Many countries acknowledged the need to establish victims' rights in legislation, and such acknowledgement was indeed formulated in 1985, when the United Nations signed a treaty that called for justice with those victimized by criminal activities. The treaty calls for an adaptation of both national and international norms that guarantee access to justice, fair treatment, compensations and aid for victims of criminal offenses. The treaty encourages legislators in different countries to formulate a legal administrative infrastructure in order to increase victims' involvement in the judicial process, while also providing them with aid and protection as needed (Yanai, 2003). The need for recognition, from different institutions within the criminal justice system, in the rights of the victim stem from the fact that in addition to the first trauma and suffering of being a victim, a 'secondary victimization` occurred during encounter with criminal justice agencies. Such secondary victimization is a product of two main causes:

1. Victims are not always familiar with the criminal procedure. Consequently, they may experience high levels of stress and anxiety, while many of their questions may be left unanswered. Victims are usually not aware of the different stages of the criminal procedure, the length of time and duration of each stage of the procedure, the decisions that may result from each stage, and also who is to inform them of the various stages and procedure if at all.

2. Victims do not have a legal stand in criminal procedures under the adversarial system-state versus the accused-hence the evidence provided by victims and their family members are not represented during the process and have very little input, if at all, during the criminal procedure (Goldsteen, 2008). 


\section{SECONDARY VICTIMIZATION}

The encounter and interaction with the criminal justice agencies has the potential to increase feelings of secondary victimization among certain victims. During the pre-trial period and investigation, details about the offense and the identity of those involved, including the victim and members of his/ her family, may be open to the media. This period is also characterized by increased uncertainty, stress, and emotional instability. During the trial period-which usually may stretch over a long period of time-victims are often found in situations of uncertainty of the different trial stages and scheduled hearings, as well as scheduled dates for decisions and final judgment (Erez, 1999; Shoham \& Regev, 2008). The unknown and constantly changing schedule of court appearances for testimony and consequent anticipation of the victim, contribute to increase in anxiety, stress and frustration that in turn may affect the victims trust in the criminal justice ability.

In cases when the trial ends with an acquittal of the accused-even if such acquittal is due to lack of reasonable doubt and insufficient evidence-the victim has to deal with a dishonesty label of a "pretender". On the other hand, when the trial ends in conviction, the victim's role seems to end, and they are left to their own devices; there is no regulated policy that aims at taking care of the victim's wellbeing and her/ his physical, mental and emotional rehabilitation (Johnston, 1997; Weisburd \& Braga, 2006).

Possible solutions to reduce and minimize secondary victimization may be achieved by providing the victims and their families with general information on how the case is progressing while providing dates of court deliberations. Another method of reducing feelings of secondary victimization is by conveying to policy makers the needs of victims and their families (Shoham, 2004a; Shoham \& Regev, 2008). Such approach may result in a sincere and sympathetic atmosphere for the victim, a pivotal entity in the criminal procedure.

\section{VICTIMS IN THE AMERICAN CRIMINAL JUSTICE SYSTEMS}

According to Gross (2002) most western countries are based on a criminal justice system that limits their criminal procedures to that of the state versus the accused. Therefore the state carries the responsibility of bringing criminal offenders to trial, and when found guilty to punish them; with the prime aim of deterrence (both individual and general deterrence). The United States initiated a presidential committee in 1980's that aimed to investigate the status and rights of victims. This committee resulted in legislating federal laws that secure the status and rights of victims in the criminal procedure (U.S. Department of Justice, 2004). Such legislation constitute the framework that established victims rights in a national level, while also encouraged and initiated support and assistance programs in local levels (Yanai, 1994).

The legislation of the Victim and Witness Protection Act (VWPA) of 1982 brought victims status and legal rights to public awareness. The legislation regulated guidelines for fair treatment of victims and witnesses in federal trials and resulted in the legislation of additional laws and regulations profiting victims and witnesses. Among these, is the legislation of the Victim of Crime Act (VOCA), in 1984, that supports different states in the United States to establish local support programs for victims and enables easy and equal access to support and compensation across the United States. This law resulted in the establishment of the Office for Victims of Crime (OVC) that supervise the administration of federal victims programs while also coordinating such programs in local states; such programs had to comply with legal definitions set forth by federal legislation ${ }^{6}$. In fact, in 1984 amendment to the Victims of Crime Act (VOCA) called for leadership and funding on behalf of crime victims. Consequently, in 1988 United States congress formally established the Office for Victims of Crime (OVC) as a federal entity affiliated with the office of justice programs (U.S. Department of Justice, 2004). Specifically, the OVC mission "...is to enhance the Nation's capacity to assist crime victims and to provide leadership in changing attitudes, policies, and practices to promote justice and healing for all victims" (U.S. Department of Justice, 2004 p. 1).

In 1996, congress was presented with a request to amend the constitution by including victims' rights in the amendments (Gross, 2002). Specifically, President Clinton called to amend the constitution so that "government does not trample on the rights of the victims" (retrieved from http://millercenter.org/scripps/ archive/speechs/detail/4596 on Dec. 19th 2013). By

\footnotetext{
${ }^{6}$ The general UN assembly posted on November $29^{\text {th }}, 1985$, a declaration in regard to "basic regulations of delivering justice to victims of crime" (as follows: declaration of victims of offense), which calls to acknowledge the needs and rights of such victims on the various levels, such as compensation and assistance, among other.
} 
that a call to match the rights of victims with those of the accused was made. This proposed amendment offered various legal rights to victims of violent offenses, including the invitation to actively participate in all legal procedures; conducting a speedy trial; right to request restitution from the offender; assurance for the safety of the victim and his/ her family to be factored into the offender release considerations; and the obligation of the state to treat the victim, among other rights ${ }^{7}$. Although amendment to the US constitution was never achieved, all 50 states of the United States acknowledged the need to address the pressing issues of victims' rights in their relative constitutions.

Eight common domains reflecting victims' rights became the center of discussion for each of the fifty states; these domains were partially included in the Israeli Crime Victims Protection Act legislated at the beginning of 2000, as will be discuss later in this article.

1. The right to inform the victim - mandated informing the victim of any decisions, actions, or meaningful events occurred during the criminal procedure. Events such as rescheduling, nullification of the trial, plea bargaining, decisions on release from arrest/ incarceration of the accused, pardons, release from psychiatric observation/ treatment and the like.

2. The right to be protected from the offender refers to restriction orders, release on bail, and the like.

3. The right to be a part of the prosecution decision making - includes decision in regard to plea bargaining, payment for laboratory exams for sex-offense victims.

4. The right to be heard - secure the victims right to voice his/ her experience in different ways than the one recorded by the victims impact statement.

5. The right to actively participate in the trial in spite of the fact that the victim has the status of a prosecution witness.

6. The right to restitution - introducing a mandatory right for compensating the crime victim in the criminal procedure.

\footnotetext{
${ }^{7}$ For a full discussion on the proposed amendment refer to the Victims Witness Assistance Program (VWAP) at: http://www.vwapwv.com/amendments.html (last visited December $31^{\text {st }} 2013$ ).
}

7. The right to privacy - many victims feels uncomfortable in being exposed to the public, while others may fear retaliation or harassment. Such concerns prevent many victims from contacting criminal justice agencies.

8. Adhering all above rights to victims of minor offenses as well.

\section{VICTIM'S STATUS IN ISRAEL}

The Crime Victims Rights Act of $2001^{8}$ is the first milestone that indicates institutional acknowledgement of crime victims' rights in Israel. Before this act there where couple of specific provisions that dealt with victims rights in general and the rights of crime victims in particular. Among such provisions is Article 63 to the Israeli Procedural $\mathrm{Law}^{9}$, directing the prosecution to provide the victim with detailed information on the decision not to investigate, or not to prosecute the offender. Article 64 to the Israeli Procedural Criminal Law enables the victim to appeal such decision to the legal counselor of the government, whereas articles 6873 enable victims of specific offenses to self initiate criminal procedure against the offender. Article 77 of the penal $\operatorname{code}^{10}$ further expends victims' rights by enabling judges to impose monetary restitution in a sum of no more than $228,000 \mathrm{NIS}^{11}$ (equivalent to about $\$ 65,087$ taking into consideration a currency exchange of $\$ 1=3.503 \mathrm{NIS}$ published on Dec $23^{\text {rd }} 2013$ ), on the offender, as compensation for damages and suffer caused by their criminal act.

The Israeli legislator, in Article 187(A) of the Israeli Criminal Procedural Law of 1982, also determined that the court may hear the victim's statement before sentencing. In an amendment published toward the end of the 90's, it was recognized that upon conviction and during the sentencing stage the court is entitled to instruct the probation services to provide it with an assessment evaluating the condition of the victim and the damage caused to him/ her as a result of the offense, as long as the victim agrees to such an assessment. This amendment was applied to sexual victimization. Further, the law states that while taking into consideration the best interest of the victim, it does not have to present such assessment, or parts of it, to

\footnotetext{
${ }^{8}$ Published in March $21^{\text {st }}$, 2001, page 183 in the national legal Journal, and was reprinted again on May $24^{\text {th }} 2001$ on page 390 in the national legal Journal. ${ }^{9}$ Israeli Criminal Procedural Law [integrated version], 1982.

${ }^{10}$ Israeli Penal Law of 1977.

${ }^{11}$ Updated and current from May $20^{\text {th }} 2007$
} 
the defense attorney. According to the Israeli Criminal Procedural Law, judges are authorized to discuss cases behind closed doors in order to protect the witness; prevent any publicity or identification of a minor or vulnerable victims; as well as victims of sexual offenses, prostitution, and/ or pornography in cases where there is a need to protect the victim. Such procedure is seemingly essential to secure victims and witnesses safety and willingness to testify in highly sensitive trials such as sex crimes and other cases that deal with sexual misconduct.

Below we elaborate on the Israeli Crime Victims Rights Act of 2001, and three of the basic rights that are guaranteed under this Act:

\section{The right for protection under the Israeli Act; \\ 2. The right for information; and \\ 3. The right to be heard}

\section{The Right for Protection under the Israeli Act}

According to the Crime Victims Rights Act of 2001 Article 6 , victims of criminal offense are entitled to a number of protections from suspects, accused, their family and relatives. The victim is entitled to be protected, as much as possible, during all stages of the criminal procedure. The above Article 6 mainly acknowledges the confidentiality that is associated with information available from law-enforcement agencies in regard to victims' protection and when necessary in the victims' homes in cases of domestic disputes. This is different from other countries, where physical protection such as the witness protection programs (Spenser, 1997), were not available in Israel till recently ${ }^{12}$, when the Israeli Ministry of Internal Affairs assumed such responsibility. Under the Act, limitations exist only for sharing the victim's information. More specifically, governmental entities may not provide individuals-including the defendant and his/ her attorney - with personal details and information on the victim sexual assault cases and cases of severe violent

\footnotetext{
${ }^{12}$ The Israeli government decided in January $1^{\text {st }}$ of 2006 to establish accept the recommendations of the establishment and steering committee teams and to establish the Israeli Witness Protection Program (IWPP). Per the recommendations, the Israeli Ministry of Internal Affairs assumed responsibility over IWPP, which gained more attention only recently. However, this program deals mainly with the protection of very limited number of witnesses who are considered to be in a life threatening situation that results from their testimony. These are usually organized crime witnesses and other, mainly, large scale criminal cases considered to be severe crimes. See following link (in Hebrew): http://mops.gov.il/CrimeAndSociety/WitnessProtection/Pages/WitnessProtectio nBackground.aspx (last visited Dec. $31^{\text {st }}$ 2013).
}

offense; such proscription can only be nullified by specific authorization from the victim. Further, a prosecutor is banned from sharing any personal information of sexual or serious violent crime victims if she/ he have the reason to believe that such information may affect the wellbeing of the victim.

A comprehensive evaluation of the 2001 Act resulted in a proposition to establish an agency under the auspice of the Ministry of Justice to protect witnesses. The committee also recommended that an independent professional agency will be established. Such agency should provide response to the various and complex needs of witnesses. In 2006, such witness protection agency was established under the auspice of the Internal Security Office (ISO) and toward the end of 2008 (on November $16^{\text {th }}$ 2008), the Israeli Parliament authorized the bill that aimed to provide witness protection act that will regulate the functions of the protection agency. The cost of such legislation was estimated at \$25.4 million, which resulted in a moratorium of the said legislation till this day ${ }^{13}$.

\section{The Right for Information}

Victims of crime often feel that they are left in the dark in regard to the legal process. One of the most prominent difficulties faced by victims of crime is the lack of information and understanding of the legal procedures in their relative cases. According to the Crime Victims Rights Act all victims of crime are entitled to information on the ongoing legal procedures in their case, as well as specific information on the procedural stage of their case, and in regard to the criminal act that resulted in their victimization; although, such information is available through the appropriate authorities, mainly the criminal justice system, and in particular the prosecution. Yet violation of this law does not constitute a criminal sanction, and is defined only as disciplinary offense.

Victims' rights are further embodied in the Crime Victims Rights Act that provides guidance as to the specific rights entitled to the victim, the manner in which the criminal procedure is administered, specific stages of the investigation in the process, and their advancement. However, such right for information is limited to exclude information that is prohibited, or otherwise may jeopardize the investigation. Victim of

\footnotetext{
${ }^{13}$ Currently, only limited prosecution witnesses enjoy the benefits offered by the Israeli witness protection program. These are usually associated with organized crime.
} 
sexual or violent offense may request from the office of pardons to be informed on requests for clemency by the offender, and also the President's decision on such requests ${ }^{14}$.

On another level, the victim has the right to examine the charges compiled by the prosecution against the offender, and also to receive a copy of such charges, excluding in cases of special and extreme conditions where such information may result in negative implications on the trial. In cases of sexual victimization, the victim reserves the right not to be questioned about her/ his previous sexual conduct and/ or previous sexual contacts with the alleged offender, and the investigation should be limited to the circumstances at hand. When such past conducted is necessary for the investigation, information on the victim's past sexual conduct will be obtained while taking into consideration the victim's dignity and privacy. Victims of sexual or violent assault are allowed to have another person accompanying them during police questioning. Additionally, crime victims have the right to be notified on developments pertain to their case, such as: when the police decided not to pursue with the investigation or prosecution; close the case; transfer the case to the prosecutors office for prosecution; information regarding the release of the alleged offender or suspect from jail; and if so, what are the restrictions and conditions associated with the release for the purpose of designing an appropriate protections for victim (Shoham \& Regev, 2008). However, Shoham (2004b) in her study on domestic violence victims found only $40 \%$ of the victims who reported the incident to the police received any explanation and guidance as to their rights.

\section{The Right to be Heard}

The right to be heard is given to victims of sexual offense and/ or severe violent offense as defined by the Israeli legislator. Under such right the victim should be informed if the criminal procedure against the offender is deferred. Such right also enables the victim to communicate his/ her concerns before plea-bargaining discussions takes place, and only in extreme circumstances can the victim be stripped from her/his right to heard. Such situation is limited to cases where the District Attorney makes the case that the victim's

\footnotetext{
${ }^{14}$ Different from the US where both the US president and governors enjoy the right to pardon offenders, in Israel the sole responsibility for pardoning convicted offenders lay within the authority of the President.
}

testimony may bias the criminal procedure (Harnon, 1997). Although the victim has the right to present his/ her testimony in cases of plea-bargaining, the court is not obligated to accept it. In fact, both Sebba (2000) and Kama (2008) acknowledge that in most recorded plea-bargaining deals the victim's testimony was excluded. However, the victim's impact statement can be presented during the sentencing stage, and in particular in cases of sexual offense and severe violence, where the victim has the right to play a more active role in furlough and parole discussions.

His honor, Judge Zeltzover (2004), reflected on the process, stating that the right of the victim to be heard during the criminal process is being followed in many cases only formally; however, many times such testimony is not taken into account toward the verdict and sentencing considerations.

On the other hand, in 2002, Article 59(a) was approved as an amendment to the Israeli criminal procedural law.

The amendment makes it difficult for those victimized by their partner/ spouse to request that the charges will be dropped, in cases of sexual or domestic violence. As such, the amendment and corresponding right of the victim does not guarantee the dismissal of charges, or even that the case will be sealed. Various steps, provisions and requirements are outlined to limit the ability of retracting complaints and before such disposition becomes possible (for further discussion on the procedure in domestic violence cases, see Landau, 2000).

Sharing the experience of victimization is of great importance to victims, who can feel empowered by this opportunity to contribute to the criminal procedure and process. Erez Klichling and Wemmers (2011) argue that such process has a therapeutic aspect to it, in what they refer to as therapeutic jurisprudence and victim participation in justice. According to Erez (2000) victims want to feel that decision makers acknowledge and value their input by considering their occurrence in the criminal procedure while at the same time recognize and consider their legitimate concerns in the case. For example, in cases of sexual assault, were plea-bargain is expected, allowing the victim to express her/ his views on the process may provide the victim with a sense of participation and control over the process, and as a result may ease the victim's difficulties to coop with the criminal procedure (Erez, Roeger, \& Morgan, 1994). Such feeling of being a part 
of the process, regardless of its outcomes, is desirable. Unfortunately, in most plea bargains, done in Israel, the victim's voice is not heard and thus results in diminished sense of control and increase feeling of being ignored by the process.

Currently, the rights protected under legislation are limited, due to the fact that in many cases the victim's statement is forwarded to the judge in writing and not directly and informally. Furthermore, victims do not have the right to be heard during the sentencing phase. Additionally, when a potential plea-bargaining is discussed, the prosecutor can fulfill its obligation to the victim by following the Israeli legislation instructing him to inform the victim on the details of the potential agreement. The Victim of Crime Protection Act provides only partial response to such perceived unjust process by allowing those victimized by sexual or violence crimes to submit a written statement on the damages caused to them by the offense; this statement can be presented during the sentencing phase. The importance of this arrangement is in creating a mechanism that provides victims with the opportunity to bring the specifics of their victimization to the awareness of the court-even if this is not being done by the victim himself/ herself-which many times is neglected during the criminal procedures, and especially when a plea-bargaining is signed (Shtienberg, 2001). Such opportunity to share details of the incident with the court during sentencing deliberations may strengthen and empower the victim while providing him with feelings of content from the way in which the process is conducted (Roberts \& Erez, 2004).

\section{Victims Interaction with Law Enforcement in Cases of Domestic Violence}

This section discusses victims' interactions with law enforcement in an attempt to better understand the importance and representation victims' experience during the criminal justice process. As such it is important to discuss how victims are perceived in the criminal justice process. Contact with law-enforcement occurs when the victim is initially questioned by the police officer. Many times, the police officer becomes the correspondent to the anger and feelings of helplessness experienced by the victim, as well as to her/his frustration (Shoham, 2000). Yet, such initial interaction is of great importance to both victims and consequent criminal process. Unfortunately, many times law-enforcement agents lack the proper training to assist the victim, or even to provide comfort at the initial stages, as in many cases of domestic violence (see Erez \& Blankap, 1998; Shoham, 2004b). Specifically, it was found that the interaction of victims with police officers was characterized by lack of trust and disappointment (Shoham, 2012). Moreover, Coulter, Kuelter, Byers, and Alfonso (1999) argue that women who are victims of domestic violence tend to fear future retaliation by their assailant (e.g. partner/ spouse) and therefore are less likely to cooperate with the officer.

Studies conducted in Israel found that officers tend to be suspicious, and untrusting toward women filling a domestic violence complaint (Shoham, 2012). Many times the officers on the scene perceive the woman as not taking responsibility for her fate, and at times even as dragging the officer into a dispute that is not of their concern. The officers' tendency is to view domestic violence and violence against women as a civil therapeutic issue and not as an enforceable criminal case. Such approach leads to further alienating the victim from the process, and consequently reduces the will of law-enforcement (and potential prosecutors) to involve the victim in the criminal process. It is important to understand such dynamic as it contributes to de facto silencing of domestic violence and sexual assault victims in the process (Shoham, 2012). Erez and Blankap (1998) found evidence suggesting that beyond the cold and unsympathetic attitudes of officers toward those women victimized by domestic abuse and violence, many officers lack the understanding and sensitivity, and some even approach the victims with hostility. Thus the interaction with law enforcement is perceived by the many women, who are victims of domestic violence and abuse, as extremely discouraging which in turn leads to under reporting of domestic violence cases.

On the other hand, many victims of domestic violence who report their victimization tend to change, or even withdraw, their initial complaint (Shoham, 2004a). Such lack of consistency that leads to the nullification of the complaint results in a condescending and disrespectful attitude by the responsible lawenforcement officer, who is not empathetic to the situation, and who may become reluctant to invite victims of similar circumstances to take part in the legal process. Such approach may be the result of poor training as well as lack of sensitivity to delicate situation the victim is in (e.g. many women need to return and live with their attacker/ abuser). Many studies demonstrated that there is a gap between women expectations of the officers and the actual behavior and 
demeanor of the officers who deal with the case (Bachman \& Coker, 1995; Erez \& Blankap, 1998; Hoyle \& Sanders, 2000; Eisikovits, Griffel, Enosh, Buchbinder, Goldblatt, Grinshtain, Winstok, \& Koresh, 1998). Domestic violence victims that decide to report their abuse do so after overcoming many impediments and psychological barriers, where they have to overcome feelings of fear, shame, failure, and many times even a fear from a potential escalation of the violence as a result. Shoham (2004a), who examined the perspective and experience of women victimized by their spouse while dealing with the Israeli police, found that such enormous difficulties usually create an expectation from the officers to be more understanding and supportive. In fact, Coulter and her colleagues (1999) who examined the interaction of 498 battered women in Florida's shelters with responding police officers concluded that more systematic training for the officers is needed to develop an objective response to domestic violence cases, a response that is not influenced by the officer's personal history and believe. Different researchers (Bachman \& Coker, 1995; Shoham, 2012; Websdale \& Johanson, 1997) claim that women who are exposed to domestic violence tend to perceive the police as an enforcer whereas the arrest is only an immediate solution designed for their immediate protection and as a source of coercion on the attacker to seek treatment and less as a punitive sanction. Differently put, women who were victimized by their spouse sought police assistance as an immediate solution to stop the violence and to force the abuser to seek help. On the other hand, many lawenforcement officers feel that law-enforcement involvement that does not result in incarceration or in prosecution is a waste of their time. As a result, police officers frequently feel frustrated when they attempt to aid the victim by placing the attacker under custody while the victim ends up dropping the charges. To the officers involved, such behavior is wrongly interpreted as false cry for help and at times as an instrumental attempt of the victim to gain something from her spouse and attacker (Balknap, 1995; Zalzover, 2004). Such disconnect is not conducive to either sides, and may be an important factor in our attempt to understand the diminished role of the victim in the process, and later during the sentencing stages.

Despite visible efforts to strengthen and empower victims of domestic violence (DV) to report their victimization, and thus voicing their experience (Shoham, 2012), such effort are not widely accepted by law-enforcement investigators which continue to perceive their role as enforcers and not as therapists. Only $20 \%$ of the police officers who received the special DV training think that part of their role is also to provide emotional support to the victim (ibid). However, the right of the victim to be heard and to receive information on how the case is processing creates a paradox. It seems that the desire to make both enforcement and punitiveness in DV cases more serious resulted in the strengthening of a paternalistic approach, according to which law-enforcement defines itself as acting on behalf of the victim and her own good. Such approach may cast shadow on the victim's actual needs (Barak-Erez, Ynisky-Ravid, Biton, and Fogatz, 2007; Hoyle, 2007; Kamir, 2002, Radai, 1995; Landau, 2000). At the same time, the introduction of Community Policing philosophy to the Israeli Police at the beginning of 2000, resulted in furthering the paternalistic approach, and in particular in communities that are culturally homogenic, such as the case in Arab communities. In those communities victims of DV are silenced, and their voices were replaced by that of the men who consider the reputation of the family and community above that of the victim (Adelman, Erez, \& Shalhoub-Kevorkian, 2003; Shoham, 2012).

\section{ATTEMPTS TO ENGAGE VICTIMS OF DOMESTIC VIOLENCE}

Recently, law-enforcement agencies around the world became aware of the importance of addressing victims' needs, and thus began to develop more efficient support programs to assist victims of crime by both volunteers and law-enforcement officers (for a discussion on the role of "Reassurance Policing" strategies see Millie \& Herrington, 2005). Similar initiatives are currently practiced by few police precincts in Israel, where a designated social worker is assigned to victims of sexual and domestic violence offenses during the different stages of the criminal procedure. The assigned social worker does not only provide the victims with information on the criminal charges against her assailant, but also explain the victim-in cases where a decision was made to close the case-why such result occurred, in an effort to prevent secondary victimization. If requested by the victim the prosecutor dealing with the case should also explain the characteristics of the criminal procedure ahead, and the arguments to the dismissal of the case, or parts of it. Nevertheless, it seems that in addition to the protections established under the Victims Protection Act there is still room for realization of number of orders by the Israeli Police that were aimed to reassure that victims of crime will receive respectful, 
proper treatment while maintaining their dignity (for further description of the victim police interaction see Rosenbaum, 1995).

The complex and somewhat paradoxical interaction and consequent dynamics that associate with victims of domestic and intimate relations, presented in this section serves as an example to the importance of victims' participation in the criminal justice process, and consequent sentencing.

\section{The Victim's Voice - Victims Impact statement (VIS) In Israel}

Resulting from several reforms introduced by the legislator, the victims' impact statement was factored into the criminal procedure in response to the special needs and feelings experienced by victims of crime during the criminal procedure. As explained earlier, according to the adversarial system the state represents the victim, and as such leaves very limited to no room for her/ him to manifest his/ her needs; therefore ignoring and neglecting the actual victim. The victim's situation, opinions, and feelings were conceptualized as none relevant as far as the criminal justice system was concerned (Ashworth, 1998). The focus on victims as the "forgotten people" was revived in western countries due to few reasons: (1) public and media interest in raising crime rates; (2) victim advocacy groups that demanded compensation, protection and justice; and (3) acknowledgement that the damages caused to the victims by the criminal act have long-term implications, including that of "second victimization" that results from the criminal procedure and trial (see Erez \& Roeger, 1995). Erez (1990) explain that historically one can distinguish between two main phases of the demand to implement reforms that regulate victims' status. According to Erez (1990) the first stage concentrated in stipulating the need for mental and financial aid and improvement in the way in which victims are being treated by criminal justice professionals, and in particular by law-enforcement officials. As a result of a failure in this stage, a second stage followed. The second stage is much more inclusive, and demanded to actively integrate victims in the criminal procedure, while requesting procedural changes addressing the victim as an equal and active partner during the various stages of the criminal procedure.

One of the salient changes in victims' status and integration was the "Victims Impact Statement." Sebba (1996) explains this concept as a statement that is addressed to the judge during the sentencing stages, and includes detailed information on damagesmonetary, social and psychological, and even physical—caused by the criminal act.

Yet, the victim impact statement is written in a very technical manner as it is prepared by a professional, and as such, does not reflect the victim's emotions, thoughts, and desires. In fact, it can be argued that in Israel the victims' impact statement submitted to the judge before sentencing is similar to an insurance adjuster that callously estimate and report the damages. Hence, the victim role becomes very passive, as the statement is written about him as a third party. Different from the Israeli experience, other initiatives to engage victims in the legal process are implemented in western countries, such as the UnitedStates, Canada, New-Zealand, and others. For example, in a specific model known as the "Allocution" the victim enjoys the right to speak before the court during the trial (Bierschbach, 2006). This model allows the presentation of the victim's experience in front of the court and before sentencing. The victim's right to be heard, under this model, is presented directly and is not mediated by a professional as in the Victims' Impact Statement reports. However, such option-of victims' impact statement-does exist in several states in the United States, though studies have shown that in these states most victims tend not to use such right for statement (Sebba, 1996).

Since the end of the 90's Israeli courts adopted the victims' impact statement, that became common practice in the attempt to describe the victim and the related damages caused by the offender in sex-crime cases. Such amendment is based on the understanding that the criminal act is a result of a chain of events with two focal points-offender and the victim; this is an innovative consideration of crime victims as a side that needs to be acknowledged during sentencing deliberations. The Crime Victim's Act of 2001 , Section 18, extends the right of any victim, and not just victims of sexual offense, to submit a victim impact statement (VIS). Such statement should be written to address the damages resulted from the offense including physical injury, mental harm, or property damages. However, in reality most recorded VIS are being submitted by victims of sexual offense.

It is our believe that the input of the victim's impact statement is highly important to the judge's sentencing decision, and in particular in sexual victimization cases, where many times judges sentence the perpetrator 
without proper knowledge of what became of the victim. This is due to the fact that many cases are settled by a plea bargaining where the victim does not get the chance to testify and provide their side of the story. Unfortunately, according to Shoahm and Regev (2008), this does not materialize in everyday practice albeit the ruling of the Israeli Supreme Court. The Israeli Supreme Court determined that the personal circumstances of the victim and the effect of the offense on the victim's life, as well as his/her physical and mental/emotional condition, are legitimate considerations that must be taken into account by judges before they determine the sentence. On the other hand, there is a dispute about over the legitimacy allowing the VIS to be considered during the sentencing process. Erez and Rogers (1999) argue that victim input have been controversial and confronted resistance in countries with adversarial criminal justice systems. For example Myers and Greene (2004) argue that using such statement in capital cases invites prejudice and judgments based on emotion rather than reason. Other controversies relate to VIS actual impact on the actual sentencing results (Davis and Smith, 1994).

In cases of sexual victimization the VIS may strengthen the victim trust in the judicial system and hence may result in greater willingness to actively participate in the process. The statement provides the victim with the feeling that he or she has an impact on court proceedings and that they are not just passively involved. Sexual offenses are considered to be highly traumatic events that raise feeling of anxiety and helplessness in victims. Palai (2003) argues that many times the ability to submit the victims' impact statement provides the victim with a feeling that they are not being ignored and that their experience receives representation in the process. Consequently, the statement is like a certified acknowledgement of victimization.

Submission of the statement may lead to a more proportional sentencing that will take into consideration the damages suffered by the victim (Erez \& Tontodonato, 2006). As mentioned earlier, previous to the VIS procedure, victims were deprived of their "natural right" to be an active part of the criminal prosecution, due to the monopolistic approach of the state that defined the rules of the court deliberations and the role of the prosecutor as representing the victim. Accordingly, the introduction of the victims' impact statement report-even if this is done for sexual and violent offenses only-into the criminal procedure may be seen as a necessary step in the sociopolitical agenda that seeks to empower victims by shifting some of the rights (rights that are normally reserved to the state) to the victims themselves.

Nevertheless, there are those who argue that the victims' impact statement has a reverse affect, even if such is not intended. Specifically, it is argued that VIS reports being technical actually transfer more power to the state by allowing it to further control the input being provided to the court (Sebba, 1996; 2000). Furthermore, the preparation, presentation and protection on the content of such statement are in the hands of probation and parole agencies that are responsible for such statement. Ashworth (1998) argues that in that regard the victim is perceived no more than a channel, a formal institutional function, in the criminal procedure.

Other supplemental reforms aimed at improving victims status were introduced into the criminal procedure in the United States, Canada, as well as some European countries that consider the victim's experience and opinions (for a complete literature review on the victims' impact statement around the world see Blum \& Abotbul, 2004; Erez, Kilchling \& Wemmers, 2011; Roberts, 2002). Such reforms focus on offering victims with counseling and support services, along with a demand that the criminal justice system will treat the victims empathetically while understanding and addressing their needs. It is within this context that therapeutic jurisprudence emerged in regard to victims. Erez, Kilchling and Wemmers (2011) argue that there is much to gain by rehabilitating victims as there is to gain from rehabilitating offenders, and we must not be discouraged by failure to rehabilitate offenders as victims are more amenable to rehabilitation than offenders. Indeed, some of these reforms also address the need to protect the victims' identity from the media, making the victims' testimony easier while shifting the direct responsibility of compensating the victims to the state. For example, in the UK there is a governmental agency called the "Criminal Injuries Compensation Board" that aims to provide compensation for victims of violent crimes. This agency provides a list of monetary amounts of compensation for different types of injuries caused by a criminal assault (see the United Kingdom CICB official website at: http://www.accident-compensationinformation.co.uk/html/criminal_injury_compensation_b oard.html). However, as found by Des-Rosiers, Feldthusen, and Hankivsky (1998) victims who pursue 
a civil remedy want more than just monetary compensation.

Since the beginning of this millennium, the governing perception in Europe is that maintaining the right of the victim does not jeopardize the right of the offender to receive a fair process and trial (Brienen, Groenhuijsen, \& Hogegen, 2000). Differently, the Israeli criminal justice perspective is more hesitant to embrace the views of the victim which believed to jeopardize due-process rights for the offender (Schnieder, 2001; Ben-David, 2003). In that regard-regardless of the efforts to develop pro-victim policies-the Israeli criminal justice system remains highly authoritative and patriarchal (Barak-Erez, Yniski-Ravid, Biton, \& Fogatz, 2007). Further, different approaches that support individualization and personalization of the victim (Sebba, 2000; Ben-David, 2003), along with increasing activities by victim advocacy groups, mediation and restorative justice initiatives are still under-developed in Israel, and are yet to be formally and fully introduced into the Israeli criminal procedure.

\section{The Restorative Justice Model}

Leaning on an ancient practice to solve disputes, a new approach aiming at restoring community peace emerged during the seventies (Shoham, 2006). This approach known as Restorative Justice was adopted world wide in more than 80 countries around the world. The restorative justice approach is becoming central in the criminal trial procedures and brings with it a significant change in attitudes towards criminal victims (Sherman, 2003).

The focus on violence victims and in particular those of domestic violence, revolved around the behavior of the victim as the cause of victimization. Victims' accountability was considered to be one of the prime factors in deciding on the severity of the offense and the appropriate punishment in the justice process (Sebba, 1996; Landau \& Sebba, 1998; Williams, 1999). However, with the restorative justice model a different approach was implemented, one that focuses on the subjective situation and the needs of the victim, while also restoring the peace to the community that suffered from the criminal act. Consequently, the first stage of the successful reintegration is to present the offender with the damage caused by his criminal behavior. This is done by confronting the assailant with his victim in order to promote a much needed dialogue in which the consequences of the criminal act are conveyed to the assailant. This in turn brings the victim to the center of attention, which is the main idea behind restorative justice, different from the current criminal justice system that fails to do so (Mika, Achilles, Halbert, Amstutz, \& Zehr, 2004). Restorative justice takes many shapes, and in its most basic form utilizes victimoffender mediation (VOM), which provides interested victims with the opportunity to meet their victimizer and hold him/ her accountable for their action while at the same time provide important assistance and compensation to the victim (Ignaffo \& Gideon, 2013).

As such, restorative justice relays on different approaches of arbitration and mediation, and does not deal with questions such as what was the role of the victim in the criminal act committed against him. Instead, the focus is turned to the needs of the victim, and the appropriate course of action that can reduce the harm done. Different from traditional sentencing where the state takes the role of the victim in the prosecution, and both victim and offender are passive, the restorative justice seeks a more active interaction between offender and victim, while bringing the victim to the center of the judicial discussion. The aim of this model is to amend the damages caused by the offense using a process that actively involves the offender who acted against the victim as well as the community in which the crime was committed (for a full discussion in arbitration and mediation process in criminal courts see Sherman, 2003; Ignaffo \& Gideon, 2013). In that regard, the restorative justice model takes a more holistic approach that considers both victim and community as those affected by the crime. Farkash (2001) identifies some mutual needs that are shared by all those affected by the criminal act: the need to empower; the need for order and discipline (i.e. the need to know all parts of relevant information); the need to acknowledge and validate (i.e. victims should be recognized as such); and the need to create a safe environment to resolve the criminal incident.

Unfortunately, the restorative justice model and movement that gained strength in many countries around the world during the past decade (see Sherman, 2003; Strang \& Braithwaite, 2002), or so, is not yet immersed in the Israeli criminal justice system.

Under the current Israeli criminal process, victims in Israel enjoy very little involvement and are usually very passive during the various stages of the process, albeit recent legislation such as the Victims of Crime Rights Act of 2001. Implementing restorative justice model into the Israeli criminal justice process has the ability to change such situation. Following the principles of 
restorative justice will result in a meaningful change in the status and centrality of crime victims in Israel. It will further emphasize the victims' voice that was dormant, or otherwise gagged for a long time. By doing so, victims will no longer be ignored.

However, restorative justice as a method of victims' engagement is not free of criticism. Mika and her colleagues (2004) argue that while restorative justice takes into consideration the needs to rehabilitate the offender, such needs may not be in compliance with those of the victim. Moreover, they argue, many times victims are not provided with much needed help "...to deal with their trauma" (p.33). In addition, "...restorative justice may also promote unrealistic or unreasonable goals" (ibid). In particular when the offender fails to condone his act, or when he fails to take responsibility for his actions. In fact, Mika and her colleagues (2004 p. 33) argue that:

"Restorative justice has not captured the central realities of crime and trauma from a victim's point of view. Restorative justice is the current flavor of the month, and while it may be politically astute to promote ideas of 'victim involvement' and 'victim centered', these appear to be merely afterthoughts and perhaps manipulations of the victims".

(For a full discussion see Mika, Achilles, Halbert, Amstutz, \& Zehar, 2004).

\section{Conclusion and Policy Implications}

The paper discusses the lack of presentations victims experience under the Israeli criminal procedure. It further examines the gap between the rhetoric of the Crime Victims Act of 2001, and the actual practice currently implemented. Yet, much more can be written on the importance of granting crime victims with more rights and representation and reconsider their legalistic status. However, as long as the Israeli criminal justice system continues to implement practices that are diverting the attention from the victim, such flurry of work will become redundant. Complying with the legislation on victims' rights will secure victims status and ensure that victims are aware of their rights, while also add to the therapeutic process that is much needed for victims; and in particular for domestic and sexual assault victims. On the other hand, lack of compliance with such rights may jeopardize the legitimacy of already existing regulations and may further result in their nullification. This will further maximize the harmful and anti-therapeutic effects the criminal process has on victims and their families.

Consequently, it is recommended that the existing Act of 2001 will be amended so that victims of sexual and severe violent offense can express their concern during plea bargaining stages, and also during other court deliberations on the case. This will enable victims to voice their concerns, while addressing the potential harmful consequences of such deals, and thus may also affect the court decision if to allow plea bargain deals or not.

Additionally, it is suggested that in cases where victims of sexual offense and severe violent crimes express their will to testify, such request and willingness should be conveyed to the court by the prosecutor; this should be done even in cases where the prosecutor does not concur with the victim.

Doing so will ensure that the victim perspective and experience will be brought before the court and as a result will be taken into consideration. At the same time, it is recommend that the restorative justice model will be further examined and implemented side by side with the traditional criminal procedure customary in Israel, while targeting some of the criticism presented by Mika et al., (2004). By doing so, a new approach to punishment will be promoted, such that will shift from traditional emphases-of viewing the state versus the offender-to a direct dialog between victims and their assailant while considering the needs of both, as well as the needs of the community. Although our recommendations target the Israeli procedure, they may also be implied to other locals that are currently revisiting their modus operandi in regard to the representation of victims in the criminal procedure.

\section{REFERENCES}

Abramovsky, A. (1986). Crime victims' rights. New York Law Journal, 2(3), 1-3.

Adelman, M., Erez, E., Shalhoub-Kevorkian, N. (2003). Policing violence against minority women in multicultural societies: 'Community' and the politics of exclusion. Police and Society, 7, 103-131.

Ashworth, A. (1993). Some doubts about restorative justice. Criminal Law Forum, 4(2), 277-299.

http://dx.doi.org/10.1007/BF01096075

Ashworth, A. (1998). The criminal process: An evaluative study. $\left(2^{\text {nd }}\right.$ Ed.). Oxford, Oxford university press.

Barak-Erez, D., Ynisky-Ravid, S., Biton, Y., \& Fogatz, D. (2007) Studies in gender feminism and law. Keryat-Uno: Nevo Publishing. (In Hebrew)

Bar-Zohar, Y. (2008) Victimization: Multiple causes, phenomenological prisms, and implementation perspectives. In: Kim, Y., 
Bar-Zohar, Y., and Eden, L. (Eds.) Victimization, Criminal Justice, Gender, and Society. Beit-Berel College: Massada Publishers: 467-503. (In Hebrew)

Bachman, R., \& Coker, A. L. (1995). Police involvement in domestic violence: The interactive effects of victim injury, offender's history of violence and race. Violence and Victims, 10(2), 91106.

Ben-David, S. (2003) Victimology from the Victims Point-of-View. In: Hovav, M., Sebba, L., and Amir, M. (Eds.) Trends in Criminology: Theory, Policy and Implications. Jerusalem: The Institute for Legislation Research and Comparative Law: Hebrew University: 775-796. (In Hebrew)

Bierschbach, R. (2006). Allocution and the Purposes of Victim Participation under the CVRA. Federal Sentencing Reporter, 19(1). http://dx.doi.org/10.1525/fsr.2006.19.1.44

Blaknap, p. (1995). Law enforcement officer's attitudes about appropriate responses to women battering. International Review of Victimology, 4(1), 47-62. http://dx.doi.org/10.1177/026975809500400104

Blum, N., \& Abutbol, D. (2004) Victim Survey. Jerusalem: The Institute of Criminology, Hebrew University. (In Hebrew)

Brienen, M., Hoegen, M., \& Groenhuijsen, M. (2000). Evaluation and mata-evaluation of the effectiveness of victim-oriented legal reform in Europe. Criminologie, 33(1), 121-144. http://dx.doi.org/10.7202/004710ar

Coulter, M. L., Kuelter, K., Byers, K., and Alfonso, A. (1999) Policereporting behavior and victim-police interactions as described by women in a domestic violence shelter. Journal of Interpersonal Violence. 14(12), 1290-1298. http://dx.doi.org/10.1177/088626099014012004

Des Rosiers, N., Feldthusen, B., and Hankivsky, O.A.R. (1998). Legal compensation for sexual violence: Therapeutic consequences and consequences for the judicial system. Psychology, Public Policy, and Law. 4(1-2), 433-451. http://dx.doi.org/10.1037/1076-8971.4.1-2.433

David, R.C., and Smith, B.E. (1994). The effects of victim impact statement on sentencing decisions: A test in an urban setting. Justice Quarterly, 11(3), 453-469. http://dx.doi.org/10.1080/07418829400092351

Eisikovits, Z., \& Griffel, A., Enosh, G., Buchbinder E., Goldblatt, H., Grinshtain, M., Winstok, Z., \& Koresh, Y. (1998). Police intervention in intimate violence: An evaluation study (A Research Report to Ministry of Public Security, State of Israel). Haifa, Israel: University of Haifa, Minerva Center for Youth Studies (In Hebrew)

Erez, E. (1995). The Effect of victim impact statement on sentencing patterns and out come: The American experience. Journal of Criminal Justice, 23(4), 637-375. http://dx.doi.org/10.1016/0047-2352(95)00026-M

Erez, E. (1999). Who is afraid of the big bad victim? Victim, Impact statements as victim empowerment and enhancement of justice. Criminal Law Review, 46(July). 545-576.

Erez, E. (2000) "Integrating a Victim Perspective in Criminal Justice through Victim Impact Statement", in A. Crawford \& J. Goodey (Eds.), Integrating a Victim Perspective within Criminal Justice: International Debates, Dartmouth: Ashgate, 165-184.

Erez, E \& Blaknap, J. (1998). In their own words: Battered women's assessment of the criminal processing system responses. Violence and victim 13(3), 251-268.

Erez, E., Kilchling, M., \& Wemmers, J. (2011). Therapeutic jurisprudence and victim participation in justice. In E. Erez, Kilchling, M., \& J. Wemmers (eds.). Therapeutic Jurisprudence and Victim Participation in Justice: International Perspectives, p. IX: Durham, NC: Carolina Academic Press.
Erez, E., and Roberts, J. (2007). Victims Participation in the criminal justice system. In: David, Lurigion, and Herman (Eds.) Victims of Crime, Cp. 17, 277-297. SAGE Publication.

Erez, E., Roeger, L. (1995). The effect of victim impact statements on sentencing patterns and outcomes: The Australian experience. Journal of Criminal Justice, 23(4), 363-375. http://dx.doi.org/10.1016/0047-2352(95)00026-M

Erez, E. and Rogers, L. (1999) Victim impact statements and sentencing outcomes and Processes: The perspectives of legal professionals. British Journal of Criminology, 39(2), 216-239. http://dx.doi.org/10.1093/bjc/39.2.216

Erez, E., Roeger, L., and Morgan, F. (1994). Victim Impact Statements in South Australia: An Evaluation. National Institute of Justice, Series C(6), Rockville, MD.

Erez, E \& Tontodaonato, P. (1990). The Effect of victim participation in sentencing on sentence outcome. Criminology, 28(3), 451474. http://dx.doi.org/10.1111/j.1745-9125.1990.tb01334.x

Farkash, E. (2001) Restorative Justice within the criminal trail. Jerusalem: Department of Justice, The National Center for Mediation and Dispute Resolution

Goldstein, S. (2008) Empowering the victim's role in civil and criminal procedures. In: Kim, Y., Bar-Zohar, Y., and Eden, L. (Eds.) Victimization, Criminal Justice, Gender, and Society. BeitBerel College: Massada Publishers: 170-178. (In Hebrew)

Gros, E. (2002) The constitutional rights of the victims: A comparative study. Legal Studies, 17, 419-438. (In Hebrew)

Harnon, A. (1997) Plea-Bargaining in Israel: Proper allocation of responsibilities. Mishpatim, 27, 543-582. (In Hebrew)

Holstein J.A., \& Miller, G. (1993). Social constructionism and social problems work. In G. Miller \& J.A. Holstein (Eds.), Constructionist controversies: Issues in social problems theory (pp. 131-151). New York: Aldine De Gruyter.

Hoyle, C. (1998). Negotiating Domestic Violence: police, criminal justice and victims. Oxford: Clarendon Press.

Hoyle, C. and Sanders, A. (2000) Police response to domestic violence. British Journal of Criminology, 40(1), 14-36. http://dx.doi.org/10.1093/bjc/40.1.14

Hoyle, C. (2007) Feminism, victimology and domestic violence. In: Walklate S. (Ed.) The Handbook of Victims and Victimology, Cullompton: Willan.

Ignaffo, D. P., \& Gideon, L. (2013). Restorative justice. In: Carlson, P.M. (Ed.) Prison and jail Administration: Practice and Theory. Burlington, MA: Jones and Bartlett Learning, 587598.

Kama, E. (2008) The punishment of Sex-offenders. In: Shoham, E. (Ed.) Monitoring Sex-Offenders in Israel: Punishment versus treatment. Tel-Aviv: Perlshtein-Ginosar, 135-144. (In Hebrew)

Kamir, A. (2002) Feminism, Rights, and Law. Tel-Aviv: MSHABT Publishing (In Hebrew) Kelly, D.P. (1987). Victims. Wayne Law Review, 34(1), 69-86.

Landau, T. (2000). Women's experiences with mandatory charging for wife assault in Ontario, Canada: A case against the prosecution. International Review of Victimology, 7(1-3), 141157. http://dx.doi.org/10.1177/026975800000700308

Landau, S.F., \& Sebba, L. (1998). Victim logical research in Israel: Past and current perspectives. In R.R. Friedmann (Ed.), Crime and criminal justice in Israel: Assessing the knowledge base toward the twenty-first century (pp. 359-387). New York: State University of New York Press.

Mika, H., Achilles, M., Halbert, E., Amstutz, L.S., and Zehar, H. (2006). Listening to Victims--A Critique of Restorative Justice Policy and Practice in the United States. Federal Probation, 68(1), 32-38. 
Milluie, A. \& Herrington, V. (2005). Bridging the Gap: Understanding Reassurance Policing. Oxford: Blackwell Publication.

Myers, B. and Greene, E. (2004). The prejudicial nature of victim impact statements: Implications for capital sentencing policy. Psychology, Public Policy, and Law, 10(4), 492-515. http://dx.doi.org/10.1037/1076-8971.10.4.492

Palai, A. (2003) The adult supervision services: The first fifty years. In: Hovav, M., Sebba, L., and Amir, M. (Eds.) Trends in Criminology: Theory, Policy and Implications. Jerusalem: The Institute for Legislation Research and Comparative Law: Hebrew University: 125-135. (In Hebrew)

Radai, P. (1995) On Equality. In: Radai, P., Shalev, K., and LibmanKobi, M. (Eds.) Legal Status of Women in Law and Society. Jerusalem and Tel-Aviv: Shoken, 10-63.

Roberts, J.V. (2002) The Use of Victim Impact Statements in Sentencing: A Review of International Research Findings. Ottawa: Policy Centre for Victim Issues, Department of Justice Canada.

Roberts, J.V. (2003) Victim Impact Statements and the Sentencing Process: Enhancing communication in the courtroom. Criminal Law Quarterly, 47(3), 365-396.

Roberts, J. V., Erez, E. (2004). Communication in sentencing: exploring the function of victim impact statement. International Journal of Victimology. 10(3), 223-244. http://dx.doi.org/10.1177/026975800401000302

Rosenbaum, D. P. (1995). The changing role of the police in North America: Assessing the current transition to community policing. Montreal: University of Montreal, 29-68.

Rubel, M.C. (1986). Victim participation in sentencing proceedings. Criminal Law Quarterly, 28, 226-250.

Schnieder, H. J. (2001).Victimological development in the world during the past three decades: A study of comparative victimology. International Journal of Offender Therapy and Comparative Criminology, 45(4), 449-468. http://dx.doi.org/10.1177/0306624X01454005

Sebba, L. (1996) Third Parties: Victims and the Criminal Justice System. Columbus, $\mathrm{OH}$ : Ohio State University Press.

Sherman, L.W. (2003). Reason for emotion: Reinventing justice with theories, innovations and research - The American Society of Criminology 2002 Presidential Address. Criminology, 41(1), 1-39.

http://dx.doi.org/10.1111/j.1745-9125.2003.tb00980.x

Shoham, E. (2000). The batter wife's perception of the characteristics of her encounter with the police. International Journal of Offender Therapy and Comparative Criminology, 44(2), 242257. http://dx.doi.org/10.1177/0306624X00442009

Shoham, E. (2004a) Characteristics of the interaction between women battered by their husbands and the police from the women point of view. In: Eden, L., Shademi, A., and Kim, Y.
(Eds.) Chasing Justice, Tel-Aviv: Beit-Berel College and Chrikover Publishers: 140-160. (In Hebrew)

Shoham, E. (2004b) The establishment of the domestic violence investigation unit in Israel: Lessons Learned. Police and Society, 8, 55-75. (In Hebrew)

Shoham, E. (2008) Monitoring Sex offenders in Israel: Punishment versus treatment. Tel-Aviv: Perlshtein-Ginosar (In Hebrew)

Shoham, E., \& Regev, Y. (2008) The victim's voice in the criminal procedure. In: Shoham, E. (Ed.) Monitoring Sex offenders in Israel: Punishment versus treatment. Tel-Aviv: PerlshteinGinosar , 203-219.

Shoham, E. ( 2012). A glimpse behind the walls: Violence towards women in segregated Communities. Bear-Sheva: Bialik Publishing.

Spencer, J.R. (1997). Improving the position of the victim in English criminal procedure. Israeli Law Review. 31, 286-299.

Steinberg, B. (2002) The mediation process in criminal procedures, its sources, development and the relationship between the mediation and the criminal procedures. Sharei Mishpat, 3(1), 131-164.

Strang, H., \& Braithwaite, J. (Eds). (2002). Restorative Justice and Family Violence. Cambridge: Cambridge University Press.

Talbert, P. (1988). The relevance of victim impact statements to the criminal sentencing decision. UCLA Law Review, 36, 199202.

U.S. Department of Justice (2004). What is the office for victims of crime? OVC Fact Sheet, November: Office of Justice Programs/ Office for Victims of Crime.

Websdale, N. \& Johanson, B. (1997). The policing of domestic violence in rural and urban areas: The voice of battered in Kentucky. Policing and Society, 6(4), 279-317. http://dx.doi.org/10.1080/10439463.1997.9964759

Williams, B. (1999). Working with victims of crime: Policies, politics and practice. London: Jessica Kingsley Publishers.

Weisburd, D. \& Braga, A. (2006). Police Innovations, Contrasting Perspectives. New York: Cambridge University Press. http://dx.doi.org/10.1017/CBO9780511489334

Williams, B. (1999). Working with victims of crime: Policies, politics and practice. London: Jessica Kingsley Publishers.

Yanai, A. (1994) Aiding victims of violent crimes: Issues in welfare policies. Social Welfare, 14, 129-146. (In Hebrew)

Yanai, A. (2003) Innovation in the criminal trial: Submission of sexual-assault victims impact statement by adult probation services. In: Hovav, M., Sebba, L., and Amir, M. (Eds.) Trends in Criminology: Theory, Policy and Implications. Jerusalem: The Institute for comparative law and legislation: Hebrew University, 235-272.

Zeltzover, N. (2004) Intimate domestic violence legislation trends. Police and Society, 8, 5-36. (In Hebrew)

Received on 25-11-2013

Accepted on 17-12-2013

Published on 10-01-2014

DOI: http://dx.doi.org/10.6000/1929-4409.2014.03.02

(c) 2014 Shoham and Gideon; Licensee Lifescience Global.

This is an open access article licensed under the terms of the Creative Commons Attribution Non-Commercial License (http://creativecommons.org/licenses/by-nc/3.0/) which permits unrestricted, non-commercial use, distribution and reproduction in any medium, provided the work is properly cited. 